\title{
HUBUNGAN PENGETAHUAN DAN SIKAP WANITA USIA SUBUR DALAM MELAKUKAN DETEKSI DINI KANKER SERVIK
}

\author{
Ryta Lumban Batu, Yovieta Novelarani Tarigan, Oktavia, Nurul Aswar Fadilla Daulay, Tuti \\ Handayani Lubis, Laurena Ginting, Harsudianto Silaen, Muhammad Taufik Daniel Hasibuan \\ Program Studi D-III Kebidanan, STIKes Murni Teguh \\ E-mail : laurenaginting2087@gmail.com \\ Program Studi Ilmu Keperawatan, STIKes Murni Teguh \\ E-mail : antosilaen4@gmail.com; aniel.jibril@gmail.com
}

\begin{abstract}
Cancer is the second leading cause of death globally and $70 \%$ of cancers occur in low- and middleincome countries. incidence rate of 17 per 100,000 women, new cases found $13.0 \%$ with a death rate of $10.3 \%$ per year of all cancer cases in women in the world. Cervical cancer is caused by Human Papillomavirus (HPV) infection. HPV is a viral infection that attacks the reproductive tract. It takes 15 to 20 years for cervical cancer to develop in women with normal immune systems. IVA is an alternative screening examination to the pap smear because it is cheap, practical, very easy to do and simple equipment and can be done by health workers other than gynecologists. The IVA test was carried out by preparing 5\% acetic acid and made on a cotton swap then a cotton swap was applied to the cervix and interpreted after 1 minute under bright light. The test is said to be positive if a white area is visible on the cervix. confusion about the importance of examinations, fear of the reality of the results faced, fear of feeling sick at the examination that will be faced, feeling reluctant to be examined by a male doctor or midwife and lack of family support, especially husbands. This research was conducted with a descriptive analytic research type with a cross sectional approach. The sample in this study were women of childbearing age aged $20-65$ years. $=$ 0.032 where $\mathrm{p}$ value $>0.05$. with good knowledge of WUS, the desire to do early detection is also there as well as the attitude, if the attitude of WUS is positive, then do an IVA test. Therefore, knowledge and positive attitudes are very important for women women so that it will increase awareness and interest in women in early detection of cervical cancer. Women of reproductive age should get a lot of information about early detection and the role of health workers and their families is very important to be able to provide information and support for women of childbearing age to carry out early detection of cervical cancer.
\end{abstract}

Keywords : Knowledge, Attitudes, Women of Childbearing Age, Early Detection Of Cervical Cancer

\begin{abstract}
Abstrak
Kanker merupakan penyebab kematian tertinggi kedua secara global dan $70 \%$ kanker terjadi di negara-negara yang memiliki penghasilan rendah dan menegah. incidence rate 17 per 100.000 perempuan, kasus baru yang ditemukan $13,0 \%$ dengan jumlah kematian 10,3\% per tahun dari seluruh kasus kanker pada perempuan di dunia. kanker serviks disebabkan oleh infeksi Human Papilomavirus (HPV). HPV merupakan infeksi virus yang menyerang saluran reproduksi. Dibutuhkan 15 hingga 20 tahun untuk kanker serviks untuk berkembang pada wanita dengan sistem kekebalan normal. IVA merupakan pemeriksaan skrining alternatif dari pap smear karena murah, praktis, sangat mudah untuk dilakukan dan peralatan sederhana serta dapat dilakukan oleh tenaga kesehatan selain dokter ginekologi. Pemeriksaan IVA tes dilakukan dengan menyiapkan Asam asetat 5\% dan dibuat pada cotton swap kemudian cotton swap dioleskan pada serviks dan diinterpretasikan setelah 1 menit di bawah cahaya terang. Tes dikatakan positif jika area putih terlihat pada serviks. keraguang akan pentingnya pemeriksaan, takut terhadap kenyataan akan hasil yang dihadapi, ketakukatan merasa sakit pada pemeriksaan yang akan dihadapi, rasa segan diperiksa dokter pria atau pun bidan dan kurangnya dukungan keluarga terutama suami. Penelitian
\end{abstract}


ini dilakukan dengan Jenis penelitian deskriptif analitik dengan pendekatan cross sectional. Sampel dalam penelitian adalah wanita usia subur yang berusia 20-65 tahun Pengetahuan wanita usia subur ada hubungan dalam melakukan deteksi dini kanker serviks dengan IVA Tes dengan nilai $\mathrm{p}=$ 0.000 dimana nilai $p>0.05$ dan adanya hubungan Sikap dengan deteksi dini kanker serviks dengan nilai $\mathrm{p}=0.032$ dimana nilai $\mathrm{p}>0.05$. dengan baikya pengetahuan WUS maka keinginan untuk melakukan deteksi dini juga ada begitu juga dengan sikap, jika sikap WUS positif maka melakukan pemeriksaan IVA tes. Oleh sebab itu pengetahuan dan sikap positif sangat penting dimiliki oleh WUS sehingga akan meningkatkan kesadaran dan minat wus dalam melakukan deteksi dini kanker serviks. Wanita Usia Subur harus mendapatkan banyak informasi tentang dekteksi dini dan peran petugas kesehatan dan juga keluarga sangat penting untuk dapat memberikan informasi dan dukungan bagi wanita usia subur untuk melakukan pemeriksaan deteksi dini kanker serviks.

Kata Kunci : Pengetahuan, Sikap, Wanita Usia Subur, Deteksi Dini Kanker Servik

\section{PENDAHULUAN}

Kanker merupakan penyakit yang memiliki karakterisik pertumbuhan sel yang abnormal sehingga menyebabkan kerusakan jaringan pada sel yang sehat. Kanker terjadi ketika sebuah sel mulai tumbuh secara tidak terkontrol. Pada masalah kesehatan reproduksi wanita kanker payudara dan kanker serviks merupakan kanker yang memiliki urutan tertinggi. Kanker serviks salah satu jenis kanker yang pertumbuhannya sangat pesat dan mengkhawatirkan. Kanker serviks kini menjadi pembunuh pertama yang menyerang perempuan di Indonesia (Riksani, 2016)

Kanker merupakan penyebab kematian tertinggi kedua secara global, 13\% setelah penyakit jantung, terjadi di negaranegara yang memiliki penghasilan rendah dan menegah. Jumlah angka kematian semakin bertambah sehingga kanker menjadi penyebab kematian utama diseluruh dunia. Pada tahun 2030, WHO memperkirakan kasus penderita kasus penderita kanker akan menjadi 26 juta orang diantaranya akan meninggal dunia (Depkes RI, 2015).

Data Globocan (IARC) 2012, kanker serviks menempati urutan kedua dengan incidence rate 17 per 100.000 perempuan, kasus baru yang ditemukan 13,0\% dengan jumlah kematian $10,3 \%$ per tahun dari seluruh kasus kanker pada perempuan di dunia(Departemen Kesehatan RI, 2015). 65\% kejadian kanker pada stadium lanjut dan $18,5 \%$ di usia 25-34 tahun dan yang paling tinggi terjadi diusia 45-54 tahun. Indonesia merupakan negara berkembang dengan kejadian trtinggi kanker pada perempuan yaitu Kanker serviks dan (Ayuningtiyas, 2018).

Kanker serviks disebabkan oleh infeksi HPV yang pada umumnya tidak menimbulkan gejala sampai tahap yang lebih parah. sering kali orang tidak menyadari kapan mereka telah terinveksi HPV dan banyak orang dapat menularkan infeksi HPV tanpa menyadarinya. Cara penularan kanker serviks dapat melalui jalur seksual dan non seksual. Untuk menghindari penularan melalui seksual penting untuk penting untuk menjaga konsistensi dalam melakukan hubungan seksual pada satu pasangan sedangkan untuk mencegah penularan melalui jalur non seksual dapatt dilakukan dengan meningkatkan kewaspadaan dalam menjaga kebersihan organ reproduksi wanita secara pribadi terutama saat toilet caring di toilet kantor, pasar dan tempat umum lainnya (Septadina, 2015)

Pemeriksaan IVA tes dilakukan dengan menyiapkan Asam asetat 5\% dan dibuat pada cotton swap kemudian cotton swap dioleskan pada serviks dan diinterpretasikan setelah 1 menit di bawah cahaya terang. Tes dikatakan positif jika area putih terlihat pada serviks, Pemeriksaan IVA tes menggunakan biaya yang murah, praktis dan sederhana sehingga cocok digunakan dinegara berkembang ( $\mathrm{G}$ et al., 2018). 
Faktor yang mendukung wanita usia subur (WUS) melakukan IVA test yaitu: faktor pendidikan, pekerjaan, usia, status perkawinan, keterpaparan informasi, dukungan tenaga kesehatan, rajak ke fasilitas kesehatan, KB, merokok, pola haid, dan riwayat penyakit keluarga. Masalah dalam melakukan skrining lainnya karena karena keenngana wanita diperiksa karena malu, repot, keraguang akan pentingnya pemeriksaan, takut terhadap kenyataan akan hasil yang dihadapi, ketakukatan merasa sakit pada pemeriksaan yang akan dihadapi, rasa segan diperiksa dokter pria atau pun bidan dan kurangnya dukungan keluarga terutama suami (Sari, 2017). Dari hasil penelitian Wulandari (2019) menjelaskan pengetahuan menjadi salah satu faktor ibu mempunyai menat untuk melakukan deteksi dini kanker (Wulandari et al., 2019).

Pengetahun dan sikap juga mempengaruhi wanita usia subur dalam melakukan pemeriksaan deteksi kanker servik. Maka peneliti tertarik untuk melakukan penelitian tentang Hubungan Pengetahuan dan Sikap Wanita Usia Subur dalam Melakukan Deteksi Dini Kanker Servik.

\section{METODE PENELITIAN}

Penelitian ini dilakukan dengan jenis penelitian deskriptif analitik dengan pendekatan cross sectional. Populasi dalam penelitian adalah wanita usia subur yang berusia 20-65 tahun di wilayah kerja Puskesmas Namorambe, dengan jumlah sampel sebanyak 64. Teknik pengambilan sampel dilakukan dengan purposive sampeling. Analisis data yang berupa univariat (frekuensi dan persentase) dan bivariat dengan uji chi square.

\section{HASIL PENELITIAN}

Tabel 1. Karakteristik Demografi Responden ( $\mathrm{n}=64)$

\begin{tabular}{llcc}
\hline No & Karakteristik & Frekuensi & Persentase \\
\cline { 3 - 4 } & & $\mathbf{n}$ & $\mathbf{\%}$ \\
\hline 1 & Usia & & \\
& >35 Tahun & 41 & 64.1 \\
& <35 Tahun & 23 & 35.9 \\
& & & \\
\hline
\end{tabular}

\begin{tabular}{llcc}
\hline 2 Pendidikan & & \\
& SD & 7 & 10.9 \\
SMP & 10 & 15.6 \\
SMA & 36 & 56.3 \\
Perguruan & 11 & 17.2 \\
Tinggi & & \\
3 & Pekerjaan & & \\
Bertani & 8 & 12.5 \\
& IRT & 37 & 57.8 \\
Karyawan & 8 & 12.5 \\
Wiraswasta & 9 & 14.1 \\
PNS & 2 & 3.1 \\
\hline
\end{tabular}

Berdasarkan tabel 1 bahwa mayoritas berusia >35 tahun $(64,1 \%)$. Pendidikan Mayoritas Wanita usia Subur berpendidikan SMA 36 orang (56.3\%). Pekerjaan Mayoritas Wanita Usia Subur sebagai IRT 37 orang $(57.8 \%)$.

Tabel 2. Distribusi Frekuensi Pengetahuan

\begin{tabular}{crcc}
\hline No & Karakteristik & Frekuensi & Persentase \\
\cline { 3 - 4 } & & $\mathbf{n}$ & $\boldsymbol{\%}$ \\
\hline 1 & Pengetahuan & & \\
& Baik & 6 & 9.4 \\
& Cukup & 10 & 15.6 \\
& Kurang & 48 & 75 \\
\hline \multicolumn{1}{c}{ Total } & $\mathbf{6 4}$ & $\mathbf{1 0 0}$ \\
\hline
\end{tabular}

Mayoritas pengetahuan wanita usia subur adalah Kurang 48 orang (75\%).

Tabel 3. Distribusi Frekuensi Deteksi Dini Kanker Servik dengan Metode IVA Tes

\begin{tabular}{llcc}
\hline No & Karakteristik & Frekuensi & Persentase \\
\cline { 3 - 4 } & & $\mathbf{n}$ & \% \\
\hline 1 & Deteksi Dini & & \\
& Melakukan & 19 & 29.7 \\
& Tidak & 45 & 70.3 \\
Melakukan & & \\
\hline \multicolumn{2}{l}{ Total } & $\mathbf{6 4}$ & $\mathbf{1 0 0}$ \\
\hline
\end{tabular}

Mayoritas WUS Tidak Melakukan IVA Tes 45 orang (70.3\%).

Tabel 4. Distribusi Frekuensi Sikap

\begin{tabular}{cccc}
\hline No & Karakteristik & Frekuensi & Persentase \\
\cline { 3 - 4 } & & n & \% \\
\hline 1 & Sikap & & \\
& Positif & 30 & 46.9 \\
& Negatif & 34 & 53.1 \\
\hline & Total & $\mathbf{6 4}$ & $\mathbf{1 0 0}$ \\
\hline
\end{tabular}


Mayoritas sikap wanita usia subur Negatif 34 orang (53.1\%)

Tabel 5. Analisis Hubungan Pengetahuan dengan Deteksi Dini Kanker Servik

\begin{tabular}{lccc}
\hline Pengetahuan & Melakukan & $\begin{array}{l}\text { Tidak } \\
\text { Melakukan }\end{array}$ & p \\
\hline Baik & 5 & 43 & 0.000 \\
Cukup & 6 & 4 & \\
Kurang & 5 & 1 & \\
\hline Total & 16 & 48 &
\end{tabular}

Pengetahuan WUS ada hubungan dalam melakukan deteksi dini kanker serviks dengan IVA Tes dengan nilai $\mathrm{p}=0.000$, dimana nilai $\mathrm{p}<0.05$.

Tabel 6. Analisis Hubungan Sikap dengan Deteksi Dini Kanker Serviks

\begin{tabular}{lccc}
\hline Pengetahuan & Melakukan & $\begin{array}{l}\text { Tidak } \\
\text { Melakukan }\end{array}$ & p \\
\hline Positif & 5 & 25 & 0.032 \\
Negatif & 14 & 20 & \\
\cline { 1 - 3 } Total & 19 & 45 & \\
\hline
\end{tabular}

Adanya hubungan Sikap dengan deteksi dini kanker serviks dengan nilai $\mathrm{p}=0.032$ dimana nilai $\mathrm{p}<0.05$.

\section{PEMBAHASAN}

Adanya hubungan antara pengetahuan dengan deteksi dini kanker servik dengan nilai $\mathrm{p}=0,000$ dimana nilai $\mathrm{p}>0.05$, hasil penelitian ini sesuai dengan penelitian Lestari (2016) menyatakan bahwa ada hubungan antara pengetahuan tentang kanker serviks dengan kesediaan WUS dalam melakukan deteksi dini kanker serviks di Puskesmas Manahan Kota Surakarta (p value: 0,025). Nilai Rasio Prevalens (RP) yaitu 0,358 (CI95\%=0,141-0,908) (Lestari, 2016). Hasil menunjukkan bahwa WUS yang mempunyai pengetahuan kurang berpeluang 0,358 kali lebih besar tidak melakukan deteksi dini kanker serviks dengan IVA test. Didukung oleh penelitian Batubara, 2019 yang menyatakan bahwa adanya hubungan yang kuat dan dominan antara faktor pengetahuan dengan keikutsertaan ibu dalam melakukan tes IVA di Puskesmas
Pintupadang Kabupaten Tapanuli Selatan Tahun 2019(Batubara et al., 2019).

Adanya hubungan antar sikap dengan wanita usia subur dalam melakukan deteksi dini kanker serviks dengan nilai $\mathrm{p}=0.032$, hal ini sesuai dengan penelitian Indrayani (2018) terdapat hubungan sikap wanita usia subur dengan pemeriksaan IVA dimana variabel sikap wus nilai) $\mathrm{R}=3.857$ yang berarti bahwa responden dengan sikap negatif beresiko 3.8 kali lebih besar mempunyai minat untuk IVA tes Rendah dibanding dengan sikap positif (Indrayani \& Naziyah, 2018). Didukung dengan pendapat Nurhayati, 2019 bahwa ada hubungan bermakna sikap terhadap pemeriksaan IVA dimana odd ratio 5,1 yang artinya sikap positif mempunyai peluag 5,1 kali lebih besar dibanding responden yang bersikap negatif (Nurhayati, 2019). Sejalan dengan penelitian kristisnti, 2019 adanya kekuatan hubungan wanita usia subur dengan prilaku pemeriksaan IVA tes maka disimpulkan dengan semakin besar nilai positif sikap maka semakin besar prilaku wanita usia subur dalam melakukan IVA tes (Kristiati et al., 2019). Sesuai juga dengan penelitian Indrayana, 2018 bahwa adanya hubungan sikap dalam pencegahan kanker servik dengan minat mealukan deteksi dini dengan inspeksi visual asetat.

Notoadmojo (2014) menjelaskan bahwa mata, hidung, telinga, dan sebagainya (pengindraan manusia) mempengaruhi hasil tahu (pengetahuan manusia) (S., 2014). Pengetahuan sangat dibutuhkan dalam melakukan suatu perubahan terhadap pola pikir dan perilaku inividu, kelompok dan masyarakat. Pengetahuan seseorang dapat mempengaruhi perilaku individu, namun pengetahuan tinggi tidak menjamin membuat seseorang mau sadar untuk melakukan IVA test (Inspeksi Visual Asam Asetat). Hal ini dipengaruhi oleh berbagai hal seperti budaya masyarakat yang menganggap pemeriksaan pada daerah reproduksi dianggap tabu, malu dan takut akan hasil yang diperoleh nanti.

\section{KESIMPULAN}

Kesimpulan dari penelitian yang telah dilakukan bahwa ada hubungan 
pengetahuan dan sikap WUS dengan deteksi dini kanker serviks dimana dengan baikya pengetahuan WUS maka keinginan untuk melakukan deteksi dini juga ada begitu juga dengan sikap, jika sikap WUS positif maka melakukan pemeriksaan IVA tes. Oleh sebab itu pengetahuan dan sikap positif sangat penting dimiliki oleh WUS sehingga akan meningkatkan kesadaran dan minat wus dalam melakukan deteksi dini kanker serviks tes karena semakin cepat dan dini kanker diketahui maka semakin cepat juga penanganan dan penyembuhan dilakukan. Oleh sebab itu Wanita Usia Subur harus mendapatkan banyak informasi tentang dekteksi dini dan peran petugas kesehatan dan juga keluarga sangat penting untuk dapat memberikan informasi dan dukungan bagi wanita usia subur untuk melakukan pemeriksaan deteksi dini kanker serviks.

\section{SARAN}

Wanita Usia Subur harus mendapatkan banyak informasi tentang dekteksi dini dan peran petugas kesehatan dan juga keluarga sangat penting untuk dapat memberikan informasi dan dukungan bagi wanita usia subur untuk melakukan pemeriksaan deteksi dini kanker servik.

\section{REFERENSI}

Ayuningtiyas, I. (2018). Hubungan antara dukungan suami dengan sikap istri pada deteksi dini kanker leher rahim menggunakan tes iva di puskesmas jaten ii kabupaten karanganyar. 6(2), 1-6. https://doi.org/10.13057/placen tum.v

Batubara, A. A., Dame, E., \& Friska, E. (2019). Faktor terkait partisipasi ibu dalam tes iva (inspeksi visual asam asetat) di puskesmas daerah tapanuli selatan. Jurnal Inovasi Kesehatan Masyarakat, 1(September).

Departemen Kesehatan RI. (2015). Program Nasional Gerakan Pencegahan dan Deteksi Dini Kanker Leher Rahim dan Kanker Payudara (Issue April).

G, K., kamdje A, N., Tagne R, S., Amvene J,
M., \& C, N. (2018). Cervical Cancer Screening with Visual Inspection with Acetic Acid and Lugol as Primary Screening Test, a Comparable Result to Conventional PAP Smear in Northern Cameroon. Journal of Cancer Science and Research, 03(01), 2-5. https://doi.org/10.4172/2576-1447 .1000109

Indrayani, T., \& Naziyah. (2018). Hubungan pengetahuan dan sikap wanita usia subur terhadap minat melakukan iva di puskesmas jatinegara. Kesehatan Masyarakat, 4(2).

Kristiati, S., Titisari, I., \& Nurfiani. (2019). Hubungan sikap dengan perilaku pemeriksaan inspeksi visual asam asetat pada wanita usia subur di desa kemiri kabupaten kediri. 2(1).

Lestari, I. S. (2016). Faktor-faktor yang mempengaruhi kesediaan wus dalam melakukan deteksi dini kanker serviks di puskesmas manahan surakarta. Manajemen Kesehatan Indonesia, 5(2), 62-77.

Nurhayati, N. (2019). Hubungan pengetahuan dan sikap ibu usia subur dengan pemeriksaan iva di puskesmas sungai limau. Jurnal Akademika Baiturrahim Jambi, 8(1), 12. https://doi.org/10.36565/jab.v8i1.98

Riksani, R. (2016). Kenali kanker serviks sejak dini. Rhapa Pubhlising.

S., N. (2014). Ilmu perilaku kesehatan.No Title.

Sari, A. R. P. (2017). Pengaruh dukungan suami terhadap wanita usia subur (WUS) melakukan pemeriksaan IVA di Puskesmas Joglo II Jakarta Barat Tahun 2016. Kesehatan Reproduksi, 1 (1)(Oktober), 43-55.

Septadina, I. (2015). Upaya pencegahan kanker serviks melalui peningkatan pengetahuan kesehatan reproduksi wanita dan pemeriksaan metode iva (inspeksi visual asam asetat) di wilayah kerja puskesmas kenten palembang. Jurnal Pengabdian Sriwijaya, 3(1), 222-228. 
Wulandari, N., Astuti, T., \& Fadhilah, S. (2019). Hubungan dukungan suami dengan perilaku pemeriksaan inspeksi visual asetat (IVA ) test di wilayah kerja puskesmas cangkaringan Sleman. Jurnal Kesehatan Karya Husada, 7(1)(1), 57-65. http://jurnal.akeskhjogja.ac .id/index.php/jkkh/article/view/257 